\title{
THE ANALYSIS OF DIVIDEND ANNOUNCEMENT IMPACT ON STOCK PRICES OF BALTIC COMPANIES
}

\section{Legenzova, R., Jurakovaitè, O., Galinskaitè, A.}

The paper is aimed to analyze and evaluate the dividend announcement impact on stock prices of companies listed on the NASDAQ OMX Baltic market during 2010-2015. The analysis was performed using the market model event study analysis and calculating AARs based on 3 strategies, which assume that investors buy shares 30 days prior to the dividend announcement and sell them either 1, 3 or 7 days after the dividend announcement. During the research period, dividends were paid by 40 out of 72 companies listed on the NASDAQ OMX Baltic. A total of 168 dividend announcements have been made and analyzed in this paper. The results of the research revealed that within the analyzed event windows, positive AARs exist; however, they are not statistically significant. Positive AARs obtained 3 or 7 days after the dividend announcement imply that stock prices do not drop shortly after the dividend announcement, which would indicate weak NASDAQ OMX Baltic market efficiency.

Keywords: stock prices; dividend announcements; market efficiency; the Baltic States.

JEL classification: G14

\section{Introduction}

A variety of public and private financial, management, social and other information about companies is comprised within their stock prices (Chen et al., 2006). Stock prices not only include all current public or private information about a company as well as expectations of its future performance, but also respond to a new information incorporating it. If a market is efficient, stock prices should fully reflect all available information at any given point of time (Vega, 2006). As discussed by Mallikarjunappa and Manjunatha (2009) in regards to the market reaction to new information, three different forms of market efficiency exist: the weak, the semi-strong and the strong. The weak form implies that stock prices reflect all historical value-changing information, the semi-strong form means that stock prices incorporate all publicly available value-changing information, and the strong form states that security prices reflect all value-changing information, even that, which is available only to insiders and exchange specialists, including as well estimates of company performance by private users (Mallikarjunappa \& Manjunatha, 2009). Previous studies show that investors tend to overreact or underreact to new information (Chan, 2003; Chavali \&Nusratunnisa, 2013), which results in drifts of stock prices over time, thus creating abnormal return opportunities.

Changes in stock prices might be influenced by various factors. Analysis of scientific literature revealed that all the factors could be grouped into two main categories - macro factors, such as oil prices (Apergis \& Miller, 2009; Sim \& Zhou, 2015), taxes (Haesner \& Schanz, 2013), economic activity: interest rates, production, consumer prices (Peiró, 2016; Hussainey \& Ngoc, 2009), monetary policy, exchange rate (Abouwafia \& Chambers, 2015) and unanticipated inflation, risk premium (Rjoub et al., 2009) and micro factors, such a company's financial results - earnings per share, book value equity 
per share (Pirie and Smith, 2008), working capital to total assets, net profit to sales, sales to total assets (Dimitropoulos \& Asteriou, 2009), the auditor's opinion (O'Reilly, 2009) or as dividend policy (as analyzed by Chavali \& Nusratunnisa, 2013; Hashemijoo et al., 2012; Mallikarjunappa \& Manjunatha, 2009; Tauseef \& Nishat, 2015).

In the scientific literature, corporate dividend policies and their impact of stock prices are often discussed in the context of signaling theory and efficient market hypothesis; however, over the last decade scientists (Aamir \& Shah, 2011; Cozorici, 2015; Franc-Dąbrowska, 2009; Goel, 2015; Jabłoński \& Kuczowic, 2015; Kim \& Joen, 2015; Mallikarjunappa \& Manjunatha, 2009; Văidean \& Moza, 2015) have started questioning if those theories are still relevant and if the other theories such as agency and behavioral theories may be the better theoretical frameworks to explain the movements of stock prices. A literature analysis (Abbas, 2015; Awan, Bashir, 2015; Bozos, 2015; Chavali \& Nusratunnisa, 2013; Chowdhury \&Soaner, 2015; Dasilas \& Leventis, 2011; Faloye \& Oluwole, 2014; Gejalakshmi \& Azhagaiah, 2015; Laabs \& Bacon, 2013; Manzoor, 2015; Qudah \& Badawi, 2014; Stankevičienė \& Akelaitis, 2014; Sulaiman \& Migiro, 2015; Tauseef \& Nishat, 2015) revealed relatively many publications on how dividend announcements impact stock prices in different continents but in Europe, especially in Eastern Europe such literature is scarce. Previous studies checked the reliability of efficient market hypothesis in Greece (Dasilas \& Leventis, 2011; Vazakidis \& Athianos, 2010), Oman (Al-Yahyaee et al., 2011), India (Chavali \& Nusratunnisa, 2013; Mallikarjunappa \& Manjunatha, 2009), Portugal (Borges, 2009), Pakistan (Tauseef \& Nishat, $2015)$, etc. Even though previous literature regarding stock prices' reaction to dividend announcements is rather broad, as far as it is known, no previous studies in this field in the Baltic market have been conducted. Literature analysis on stock prices' reaction to other type of information across Baltic companies is also limited (Stankevičienè \& Akelaitis, 2014; Eizentas, 2012; Laidroo \& Grigaliūnienè, 2012, Laidroo, 2009). From the historical point of view, Eastern Europe has been dominated by financial intermediaries while its financial markets are less developed. On the other hand, Lithuania, Latvia and Estonia (referred to as the Baltic States) represent relatively small but fast growing EU member states competing in the global investment environment. The relevance of the research question on how dividend announcement impacts stock prices is considered to be particularly high in the Baltic States, where the economies are still considered to be in the transition period.

The paper is aimed to analyze and evaluate the impact of dividend announcements on stock prices of companies listed on the NASDAQ OMX Baltic market during the 2010-2015 period. This research seeks to explain how efficient the Baltic market is regarding dividend announcements, i.e. how fast the market reacts to new information about dividends, and if and to what extent the possibility to earn abnormal returns exists.

\section{An Overview of the Literature on Dividend Policy's Impact on Stock Prices}

Previous studies regarding dividend policy's impact on stock prices analyze this issue in different countries, across different stages of economic cycle and taking into account different dividend policies of the analyzed companies. The majority of research aims to identify whether it is possible to obtain significant abnormal returns around the dividend announcement period and how long these returns last. From this perspective, previous 
research can be grouped into 3 groups based on coherence of the results with the efficient market hypothesis, claiming that market efficiency can be weak, semi-strong or strong with respect to how much information stock prices reflect in itself and how quickly they adjust to the new information.

1) Evidence of strong market efficiency. Dasilas and Leventis (2011) employed event methodology and focused on stock market and trading volume reaction to 231 cash dividend announcements for the period 2000-2004 using data from the Athens Stock Exchange (Greece). Their findings revealed that there is a statistically significant market reaction on the dividend announcement day and the market incorporates dividend news in an efficient manner. Such results supported a signaling hypothesis. Similar results were identified by Al-Yahyaee et al. (2011) in the Muscat Securities Market (Oman) between January 1, 1997 and August 31, 2005. The research found that there is a significant abnormal return during the announcement period and even though Oman's stock market is young and investors have limited knowledge and experience, the stock market appears to efficiently incorporate dividends information in stock prices.

2) Evidence of semi-strong market efficiency. Chavali and Nusratunnisa (2013) used a sample of 67 fast moving consumer goods Indian companies and found that the market is reacting positively to dividend announcements with a significantly positive AR around the announcement date. However, the authors concluded that the stock prices adjust to the information quickly, which implies a semi-strong form of market efficiency. Chavali and Nusratunnisa (2013) investigated 137 dividend announcements on the Colombo Stock Exchange (CSE) over the period 1999-2005. The results revealed that the Sri Lanka Capital Market has a semi-strong from of efficiency because the delay of market reaction was a few days. The study of Suwanna (2012) was focused on 60 dividend announcements of companies, which were listed on the Stock Exchange of Thailand (SET) from 2005 to 2010. The positive abnormal return was observed after 2 days from the dividend announcement. Thus, the dividend announcements have a significant influence on stock prices, which confirms the dividend signaling theory.

3) Evidence of weak market efficiency. Previous studies, which report weak efficiency of the market, are rather broad. Borges (2009) examined the ex-dividend day behavior of stock prices in the Lisbon Stock Market (Portugal) over the period 1990-1998 using 446 observations from 121 firms. This study found that on the ex-day stock prices fall by the amount less than the dividend, which could be treated as an anomaly thus reflecting a less than efficient market with low liquidity levels, price stickiness, and insipid arbitrage trading. The study of Mallikarjunappa and Manjunatha (2009) examined dividend announcements of 149 Indian companies. This study found that average abnormal returns (AARs) do not approximate to zero and cumulative average abnormal returns (CAARs) show wide fluctuations indicating that abnormal returns can be earned 24 days after the event day. With regard to this, the authors conclude that the Indian market is not efficient in the semi-strong form. A. Vazakidis and S. Athianos (2010) analyzed whether dividend announcements have an impact on stock prices using a sample of 60 Greek companies listed on the Athens Stock Exchange for a fixed period, 2004-2008. The study revealed that abnormal activity in the stock market exists both prior and after dividend announcements: the market reacts positively prior to the dividend announcements, while throughout the first post-announcement days strong negative abnormal returns are observed. Abbas (2015) used the sample of 11 listed companies on the Damascus securities exchange from 
2010 to 2014. The stock prices began to adjust after 6 days and continued for at least 15 days. Therefore, the market does not adjust stock prices immediately on the day of dividend announcement.

\section{Methods}

Previous studies conducted in various countries and analyzing dividend announcements' impact on stock prices report different results, and thus imply different levels of market efficiency with respect to the speed of dividend announcement information incorporation into stock prices. As no prior research in the Baltic States has been found, it is relevant to perform research exploring Baltic market efficiency and stock price reaction to dividend announcements. The research covers the period of 2010-2015 and includes shares listed on the Baltic stock exchange. Announcements of NASDAQ OMX Baltic companies' dividends and other payouts, stock prices of companies as well as NASDAQ OMX Baltic indexes were accessed through the official webpage of NASDAQ OMX Baltic.

The Baltic stock market is represented by NASDAQ OMX Baltic and has three branches: NASDAQ Tallinn, Riga and Vilnius. In total, 72 companies are listed across all three branches. The NASDAQ OMX Baltic benchmark index (OMXBBGI) is a benchmark to all companies listed on the NASDAQ OMX Baltic equity list. OMXBBGI contains the 20 most liquid and highest capitalization companies, classified according to sectors of financial activity. OMX Vilnius (OMXV), OMX Riga (OMXR) and OMX Tallinn (OMXT) are indexes, which contain all the companies that are listed in Vilnius, Riga and Tallinn respectively.

This research was conducted in 2 stages. In the first stage of the analysis, dividend paying Baltic companies were identified. Since dividend payment is not obligatory for all companies, but rather reflects particular companies' dividend payment decision (Gejalakshmi \& Azhagaiah, 2015), the first part of this study assessed how many companies listed on the NASDAQ OMX Baltic stock exchange between 2010-2015 paid dividends and publicly disclosed such information.

The second stage of the research was aimed to evaluate dividend announcement event impact on stock prices and, similar to previous scientific research (Chavali \& Nusratunnisa, 2013; Dasilas \& Leventis, 2011; Mallikarjunappa \& Manjunatha, 2009), employed a market model event study methodology. The market model event study methodology is based on the analysis of stock price behavior during the pre-announcement, announcement and post-announcement periods. The day of dividend announcement (event day) is marked as . The range between pre-announcement and post-announcement is referred to as the event window (Bozos et al., 2011; Vazakidis \& Athianos, 2010). For simplification reasons, it is assumed that investors have a certain investment strategy with respect to the time prior to the dividend announcement (when they buy stock), and to the time after dividend announcement (when investors sell the stock), seeking for abnormal returns (AR). This research assumes that investors buy the stock 30 days prior to the dividend announcement and then sell the stock on different days, employing one of three selling strategies:

- $\quad 1^{\text {st }}$ strategy - the stock is sold at $t_{0}-1$ (i.e 1 day after dividend announcement),

- $\quad 2^{\text {nd }}$ strategy - at $t_{0}-3$, or

- $\quad 3^{\text {rd }}$ strategy $3-$ at $t_{0}-7$ 
The dividend announcement day $t_{0}$ is determined on a case by case basis for each company during 2010-2015. Under the $1^{\text {st }}$ strategy, the investor assumes that the price of the stock drops suddenly after the dividend announcement. Choosing this strategy, the investor believes that the market is efficient and the new information of dividends is incorporated into the stock price straight afterwards. Under the $2^{\text {nd }}$ and the $3^{\text {rd }}$ strategies, the investor sells stock after 3 and 7 days, respectively. These strategies show the belief that the market does not incorporate dividend announcement information into stock prices suddenly after the dividend announcement day and some type of inefficiency is observed.

The price of a stock should decrease by the full amount of the dividend on the ex-dividend day in a perfectly efficient market. Therefore, abnormal returns could be obtained only when selling shortly after the stock prices' affecting event, i.e. dividend announcement, because waiting longer would result in a drop of the stock prices. Therefore, if abnormal returns could be obtained while selling stock after 1 day after dividend announcement, this would imply that market is very efficient and stock prices drop shortly after 1 day after the dividend announcement. However, the market can be less efficient. Since an efficient market hypothesis is a simplified theoretical approach based on fundamental assumptions, which can be violated - as shown in previous studies (Borges, 2009; Mallikarjunappa \& Manjunatha, 2009; Vazakidis \& Athianos, 2010), it is important to assume that the possibility to get abnormal returns exists and the width of event window used in the research helps to represent those expectations of the possible market inefficiency. Hence, the more inefficient the market is expected to be, the wider the event window that should be used.

After constructing the event windows according to the 3 strategies defined, abnormal returns (AR) and average abnormal returns (AARs) are computed using the formulas by Bozos et al. (2011); Chavali \& Nusratunnisa (2013); Mallikarjunappa \& Manjunatha (2009); Vazakidis \& Athianos (2010). First of all, returns for the three different holding periods $[t-30, t+1],[t-30, t+3]$, and $[t-30, t+7]$, are calculated. The general formula reflects the simple percentage change in price during different holding periods. The returns of each sample stock for the 3 defined holding periods are calculated using the formula:

$$
R_{i}=\frac{P_{i t}-P_{i t-n}}{P_{i t-n}}
$$

where: $R_{i t}$ is the holding period return on stock $i$,

$P_{i t} \quad$ is closing price of stock $i$ on day $t$,

$P_{i t-n}$ is closing price of stock $i$ on day $t-n$,

$t \quad$ is day at which the stock is sold (1, 3 or 7$)$,

$n \quad$ is number of days before day $t$.

The same formula (1) is used to calculate the change of a market index. The market index is used in order to reflect the main market situation and distinguish among information, which is affecting all stocks in the market, and information (in this case - dividend announcements), related only to a particular stock. The returns of market index are calculated separately for each stock around each dividend announcement day in regards to all 3 strategies. Therefore, abnormal returns for each stock and for each of the 3 holding strategies are calculated with the formula: 


$$
A R_{i t}-R_{i t}-M_{t}
$$

where: $A R_{i t}$ is the abnormal return on a stock $i$ during the holding period (lasting up to 1,3 or 7 days),

$M_{t} \quad$ is the market index return during the holding period (lasting up to 1,3 or 7 days).

Abnormal returns for each stock and for each of the 3 strategies are summed together and divided by the number of observations in the sample. This results in the simple average of all observations in the sample:

$$
A A R_{t}=\frac{1}{n} * \sum_{i=1}^{n} A R_{i t} ;
$$

where: AARit is the average abnormal returns during the holding period (lasting up to 1,3 or 7 days),

$n$ is the number of sample stocks with dividend announcements, with abnor mal return during the holding period (lasting up to 1,3 or 7 days).

The AARs show the average deviation of the returns of the stock from their normal returns with the market index (Mallikarjunappa and Manjunatha, 2009).

For the test of significance of the results, the deviation from 0 is evaluated by $t$-test. The formula for $t$-statistics calculation is:

$$
\frac{A R_{t}}{\sqrt{S^{2} *\left(A R_{t}\right)}} \sim t(N) ;
$$

where $S$ is the standard deviation.

A level of significance of 5 percent $(\alpha=0.05)$ was chosen in this study. It is assumed in this study that abnormal returns are distributed normally. In order to justify the connection between return on stock and market index, correlation coefficients are used. Significantly close to 0 correlations are assumed to justify the existence of abnormal returns, because they would reflect stock price changes, which could not be explained by movements of the whole market.

When analyzing the dividend announcement impact on stock prices, the limitations of the research have to be taken into account. This research concentrates on a single factor, so simplification is indispensable due to the fact that in reality the mechanism of markets is very complex. Stock prices can be influenced by other micro factors and macro factors, which can affect the performance not only of the single company but also of the entire sector and economy. Another source of inaccuracy could be the dividend announcement itself. During the dividend announcement day, more information could be provided. This additional information could also have an impact on a company's stock prices. The time of dividend announcements was not taken into consideration as details on the exact hour of dividend announcement were not provided. The possibility exists that stock prices reacted during the announcement date. The research did not analyze either the tax systems of different markets or their influence on the dividend policy of the companies, dividend announcements and the stockholders' reaction to taxation regarding dividends. The size of the company was not considered. All companies were taken as equal to each other and such a factor as dividend policy decisions were not considered. 


\section{Results}

\subsection{Dividend-paying Practices of NASDAQ OMX Baltic Companies}

In general, two main dividend strategies exist: not to pay dividends (zero dividend strategy) - value for shareholders comes from additional gain due to increased stock prices; and to pay dividends. This type of strategy has various forms either in types of dividends or how they should be paid. Not all companies listed on the NASDAQ OMX Baltic have a proactive dividend policy regarding dividends payout. Less than a half of the sample companies paid dividends during the research period (see picture 1). In the second stage of the analysis, just those companies which paid dividends were further analyzed.

Figure 1 | Distribution of companies listed in NASDAQ OMX Baltic according to their dividend policy

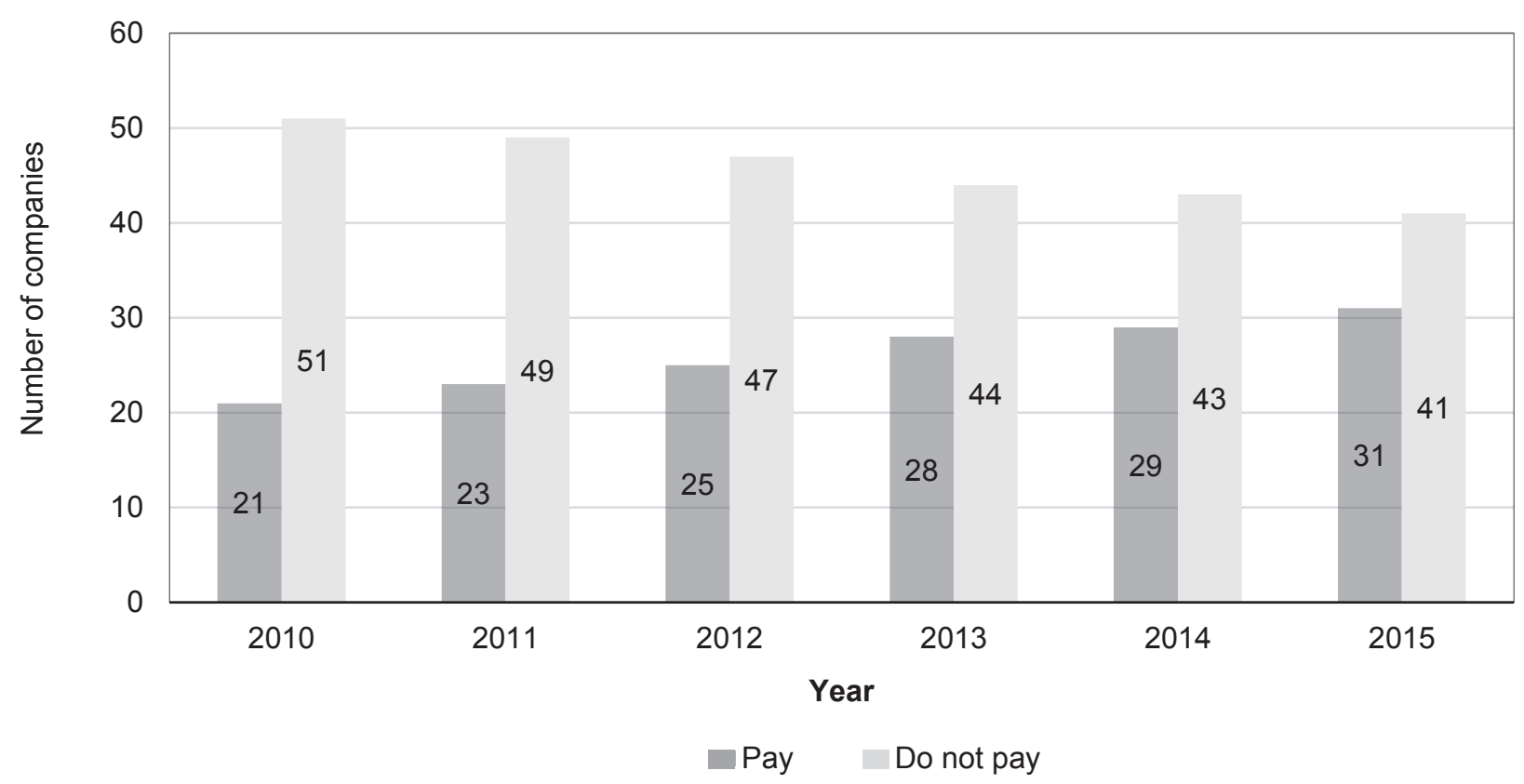

Source: Authors

Analysis of dividend announcements on the NASDAQ OMX Baltic during 20102015 revealed that companies, which paid dividends, paid three types of them: regular dividends, which are paid each year or 2 times per year; dividends, which were paid due to the reduction of nominal value of stock; and dividends, which were paid due to reduction of book value of the stock. Even so, the main source of profit in the form of dividends for shareholders remains the regular dividends (Figure 2).

Overall, the sample of total dividend paying companies varied from 21 to 33 , and a total of 168 dividend announcement (30 in 2015, 31 in 2014, 29 in 2013, 26 in 2012, 22 in 2011 and 21 in 2010) have been evaluated during the second stage of the research. 
Figure 2 | Types of dividends paid by companies listed in NASDAQ OMX Baltic

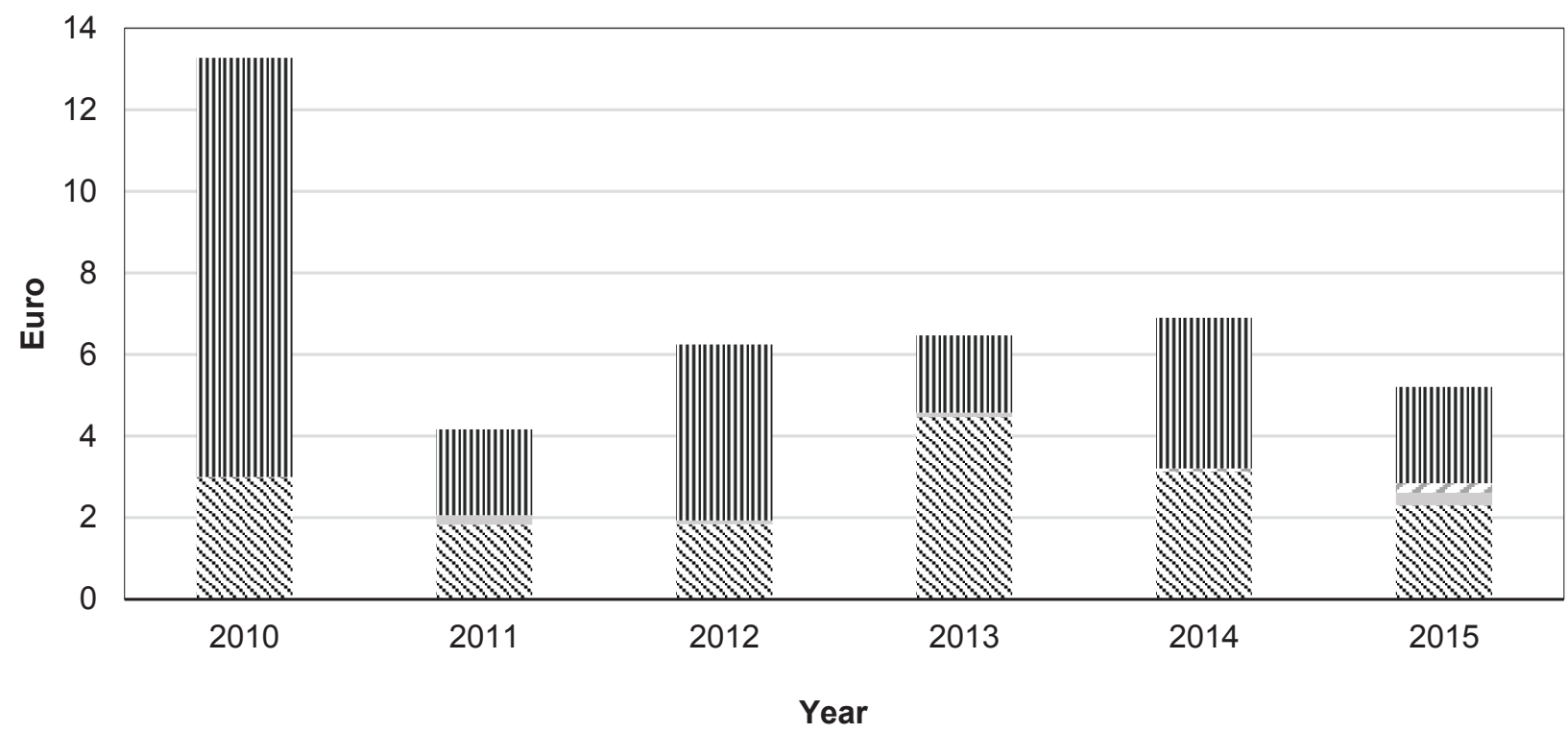

Regular main list $\quad$ Nominal main list Book main list III Regular Secondary list

\subsection{The Results of Dividend Announcements' Impact on Stock Prices of Companies Listed in NASDAQ OMX Baltic}

In order to determine the market reaction to dividend announcements, average abnormal returns around the dividend announcement period were calculated for all 3 determined investing strategies for 2010-2015. As presented in Figure 3, AARs around dividend announcement day were positive during almost the whole period of the analysis, meaning that stock price returns were higher than the index return, i.e. might have increased abnormally, because of the dividend announcement and enabled investors to obtain abnormal returns by trading stocks around the dividend announcement period.

Figure 3 | Average Abnormal Returns (ARR) of NASDAQ OMX Baltic companies

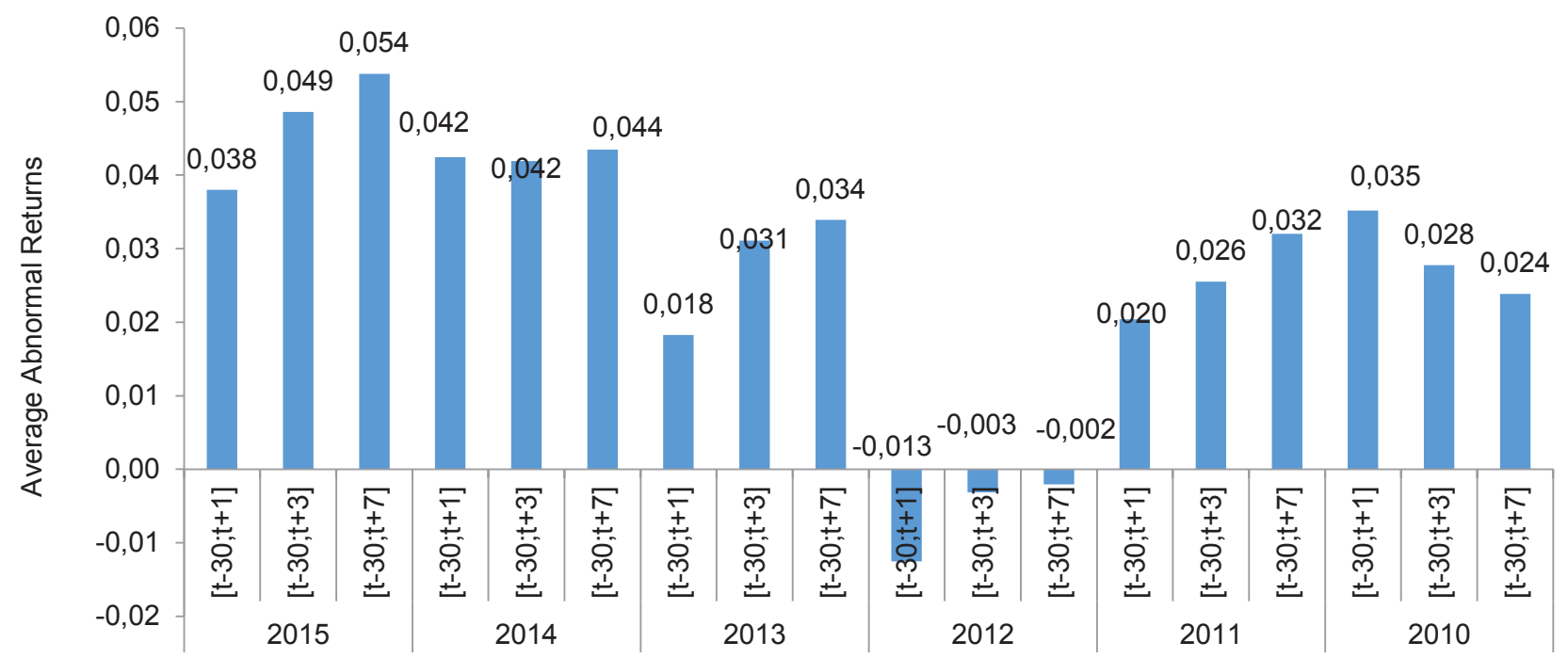

Source: Authors 
The highest AARs were observed in 2015, reaching 5.38\% when buying stocks 30 days before the dividend announcement and selling after 7 days, i.e. under the $3^{\text {rd }}$ strategy. Under the $2^{\text {nd }}$ strategy, AARs are $4.86 \%$ and under the $1^{\text {st }}$ strategy, which assumed the shortest holding period $-3.8 \%$. The second highest AARs were identified in 2014, 2011, 2013, 2010 and even negative in 2012. In 2012, AARs were negative, meaning that stock price returns were lower than index returns around the dividend announcement period. These negative AARs were influenced by the overall decreasing economic conditions during 2012 in all Baltic countries, which influenced the decreasing trend of the whole market index and decreased the stock prices of separate dividend paying companies even more. Therefore, trading for a short period around the dividend announcement could have resulted in abnormal losses. When analyzing AARs regarding the 3 different strategies, it is observed that AARs are in most cases lowest for the first strategy (buying 30 days before announcement and selling 1 day after) and increases for the second and third strategy when buying 30 days before announcement and selling after 3 or 7 days, respectively. This means that abnormal returns can be still obtained after 3 or 7 days after announcement, which reveals that stock prices did not drop shortly after the dividend announcement and indicates weak market efficiency. Nevertheless, it is possible that because of dividend expectations, stock prices reacted to expected dividends in advance and decreased before the dividend announcement. Such effect has not been assessed in this study.

In order to confirm the results of computed AARs, their statistical significance must be evaluated. For the statistical significance, $t$-statistics were computed and evaluated (see Table 1). For the statistical significance of the computed AAR, its $t$-statistics value must be higher than the critical value. As it is seen, computed AARs are significant with respect to all 3 strategies in 2015 and also significant in 2011 regarding the $2^{\text {nd }}$ and the $3^{\text {rd }}$ strategy with $95 \%$ significance level.

All other computed AARs are statistically insignificant. The insignificance of the results might have been affected by the relatively small sample size, which makes the critical value, with which $t$-statistics value was compared, higher. In addition, $t$-statistics value is affected by the standard deviation of ARs (according to the (4) formula); therefore, the higher the standard deviation of the sample ARs, the lower the computed $t$-statistics value.

In order to justify the significance of calculated AARs, the relationship between average stock and index returns 2010-2015 must be proven statistically insignificant, which would reflect that stock return volatility could not really be explained by market index return volatility. For this reason, Pearson correlation coefficients between average stock and index returns for each year separately and for the whole sample period were calculated while using SPSS statistical software. The results are provided in Table 2. 
Table 1 | NASDAQ OMX Baltic dividend paying companies' AARs and t-statistics

\begin{tabular}{|c|c|c|c|c|}
\hline Years & $\begin{array}{l}\text { Days before / after dividend } \\
\text { announcement }[t-x ; t+y]\end{array}$ & AAR & t-statistics & Critical value \\
\hline \multirow{3}{*}{2015} & {$[t-30 ; t+1]$} & $0.038^{*}$ & 2.056 & 1.699 \\
\hline & {$[t-30 ; t+3]$} & $0.049 *$ & 2.256 & 1.699 \\
\hline & {$[t-30 ; t+7]$} & $0.054^{*}$ & 2.117 & 1.699 \\
\hline \multirow{3}{*}{2014} & {$[t-30 ; t+1]$} & 0.042 & 1.167 & 1.697 \\
\hline & {$[t-30 ; t+3]$} & 0.042 & 1.137 & 1.697 \\
\hline & {$[t-30 ; t+7]$} & 0.044 & 1.148 & 1.697 \\
\hline \multirow{3}{*}{2013} & {$[t-30 ; t+1]$} & 0.018 & 1.615 & 1.701 \\
\hline & {$[t-30 ; t+3]$} & 0.031 & 1.123 & 1.701 \\
\hline & {$[t-30 ; t+7]$} & 0.034 & 1.044 & 1.701 \\
\hline \multirow{3}{*}{2012} & {$[t-30 ; t+1]$} & -0.013 & 1.378 & 1.708 \\
\hline & {$[t-30 ; t+3]$} & -0.003 & 0.582 & 1.708 \\
\hline & {$[t-30 ; t+7]$} & -0.002 & 0.471 & 1.08 \\
\hline \multirow{3}{*}{2011} & {$[t-30 ; t+1]$} & 0.020 & 1.551 & 1.721 \\
\hline & {$[t-30 ; t+3]$} & $0.026^{*}$ & 2.003 & 1.721 \\
\hline & {$[t-30 ; t+7]$} & $0.032^{*}$ & 2.252 & 1.721 \\
\hline \multirow{3}{*}{2010} & {$[t-30 ; t+1]$} & 0.035 & 1.479 & 1.725 \\
\hline & {$[t-30 ; t+3]$} & 0.028 & 1.320 & 1.725 \\
\hline & {$[t-30 ; t+7]$} & 0.024 & 1.382 & 1.725 \\
\hline
\end{tabular}

* Significant with significance level $a=0.05$

Source: Authors

As can be seen in Table 2, the lowest correlation coefficients are -0.211 in 2015 and -0.493 in 2011, which indicates low strength of the relationship. All remaining correlation coefficients are not lower than $-/+0.6$, which indicates moderate and strong relationships between average stock and index returns. The highest observed correlation coefficient is 0.964 in 2012 . The total period correlation coefficient is equal to -0.950 . The negative correlation coefficient indicates that when one of the variables is moving increasingly, the other decreases at the same time. This indicates that there is no relationship between the variables. However, at least weak relation should exist anyway, because the variation of separate stocks returns impacts the index, since the index is comprised from analyzed stocks. To evaluate the significance of these correlation coefficients, Fisher's zero hypothesis - "correlation is not statistically significant" is tested. The p-values for the significance testing were calculated with SPSS statistical software. As can be seen in 
Table 2, all p-values are higher than 0.01 and 0.05 . Therefore, all the calculated p-values confirm the insignificance of correlation coefficients for each year and total 2010-2015 period either with significance level $\alpha=0.05$ or $\alpha=0.01$. As the most confident results can be held the ones with the highest p-values, i.e. results of 2015 and 2011. Overall, it can be concluded that there is no statistically significant relationship between average stock returns and index returns during 2010-2015. Based on the results of the correlation analysis, it can be concluded that dividend announcements and stock returns relationships are significant; i.e. calculated AARs are meaningful and can be interpreted. This means that stock returns changes independently of index return changes, but reacts to the new information in the market, i.e. dividend announcement.

Table 2 | Yearly and total period correlation coefficients between average stock and index returns 2010-2015 and their significance testing

\begin{tabular}{|l|c|c|c|}
\hline Years & $\begin{array}{c}\text { Correlation } \\
\text { coefficients }\end{array}$ & p-value & $\begin{array}{c}\text { Statistical } \\
\text { significance } \\
\text { checking }\end{array}$ \\
\hline $\mathbf{2 0 1 5}$ & -0.211 & 0.865 & not rejected \\
\hline $\mathbf{2 0 1 4}$ & 0.673 & 0.530 & not rejected \\
\hline $\mathbf{2 0 1 3}$ & 0.665 & 0.536 & not rejected \\
\hline $\mathbf{2 0 1 2}$ & 0.964 & 0.170 & not rejected \\
\hline $\mathbf{2 0 1 1}$ & -0.493 & 0.672 & not rejected \\
\hline $\mathbf{2 0 1 0}$ & 0.940 & 0.222 & not rejected \\
\hline $\mathbf{2 0 1 0 - 2 0 1 5}$ & -0.950 & 0.203 & not rejected \\
\hline
\end{tabular}

Source: Authors

\section{Discussion}

The conducted analysis revealed that positive AARs can be obtained while buying stocks on the NASDAQ OMX Baltic 30 days prior the dividend announcement and selling 1, 3 or 7 days after dividend announcement, but these AARs are not statistically significant. One of the reasons for insignificant results might be the relatively small sample. The NASDAQ OMX Baltic market is not big, and the sample of total dividend paying companies varied from 21 to 33 in this study, resulting in a total of 168 dividend announcements (30 in 2015, 31 in 2014, 29 in 2013, 26 in 2012, 22 in 2011 and 21 in 2010). On the contrary, the insignificance of AARs may also indicate that the market is very efficient and there is no possibility to earn abnormal returns while trading stocks around the dividend announcement period. We suggest that such a conclusion isn't valid, because the chosen 3 stocks' holding period strategies do not allow to estimate whether stocks prices react significantly prior to the dividend announcement (and at which days exactly) because of dividend expectations or whether the stock prices react to dividend announcements after the chosen assessment period. To prove market efficiency, a more detail assessment is required. Positive AARs obtained 3 or 7 days after the dividend announcement imply that 
stock prices do not drop shortly after the dividend announcement event, which would indicate weak market efficiency. These results are in line with the study by Mallikarjunappa and Manjunatha (2009) who revealed that AARs do not approximate to zero and Cumulative Average Abnormal Returns (CAARs) show wide fluctuations indicating that abnormal returns can be earned 24 days after the event day. In addition, the results of this study can be compared to research done by Abbas (2015), which revealed that after the dividend announcements, stock prices began to adjust after 6 days and continued for at least 15 days, indicating weak market efficiency. Another reason for insignificant results might be weak overall efficiency of Baltic market, which may indicate that new information has very little effect on stock prices, the market reacts slowly and, in addition, the stock market may be strongly affected by other microeconomic or (and) macroeconomic factors. Hence, the sample of this study in further research could be enlarged by including all dividend paying companies listed on the NASDAQ OMX Nordic stock exchange.

The results of this study could be applied in practice when constructing stocks portfolio, because the results could help to evaluate possible abnormal changes in stock prices due to dividend announcement. However, the results obtained are generalized to all dividend paying companies listed on the NASDAQ OMX Baltic stock exchange; therefore, to enhance the applicability of the results, it would be useful to evaluate individual company's stock price changes because of dividend announcement. In addition, the results can serve for investment decision making by investors, i.e. the provided dividend descriptive statistics and trend analysis can help to identify dividend payment policy of particular company. This can be very useful for investors, who are seeking, first of all, the return from dividends. Moreover, the results of this study are useful for companies' listed on the NASDAQ OMX Baltic stock exchange managers, who, knowing that dividend announcement affect stock prices, can determine different periods for dividend announcement, increase / decrease dividends, thus sending the desired information into the market and thus affecting the company value.

The results obtained while using historical data do not guarantee that, in this case, it will not be possible to obtain statistically significant AARs while buying stocks on the NASDAQ OMX Baltic 30 days prior the dividend announcement and selling 1, 3 or 7 days after dividend announcement in the future, because AARs may be affected by complex interrelations among many other factors, which are very difficult to predict in an uncertain environment. Furthermore, the effect of these interrelations on stock prices cannot be captured by market model event study methodology; therefore, other methods should be applied further to address this issue.

\section{Conclusions}

1. Stock prices and market capitalization are used as proxies to reflect the value of a company at a certain given point in time, and therefore are of particular importance. Stock prices contain much public or private information about the company (micro) and its environment (macro), and all of the information (including expectations) has an influence on current as well as future stock prices. Dividends and dividend payment announcements are identified among the important factors influencing stock price volatility. Previous studies show that investors tend to overreact or underreact to new information, which results in drifts of stock prices over time, thus not accomplishing arbitrage and creating abnormal return opportunities. 
2. Previous studies regarding dividend policy impact on stock prices may be grouped on the basis of coherence with the efficient market hypothesis, claiming that market efficiency can be weak, semi-strong or strong with respect to how much information stock prices reflect and how quickly they adjust to the new information. Previous research reported disparate results with respect to market efficiency, i.e. the speed of incorporation of new information regarding dividend announcement decisions into the stock prices. In the Baltic States, studies regarding the impact of information disclosure on stock prices are limited and no previous research on the behavior of stock prices around the dividend announcement date was found.

3. To evaluate dividend announcement impact on the stock prices of companies listed on the NASDAQ OMX Baltic market, at first information on dividend paying practices of Baltic listed companies was gathered. The analysis revealed that in 20102015 a total of 72 companies were listed in the Baltic equity market, but only 40 of them paid dividends and the influence of a total of 168 dividend announcement has been further assessed.

4. Dividend announcement's impact on stock prices of NASDAQ OMX Baltic dividend-paying companies had been evaluated using the market model event study analysis and calculating AARs based on 3 strategies, which assume that investors buy the stock 30 days prior to the dividend announcement and sell it either 1, 3 or 7 days after the dividend announcement. The results of the research revealed that within the analyzed event windows, positive AARs exist; however, they are not statistically significant. Positive AARs obtained 3 or 7 days after the dividend announcement imply that stock prices do not drop shortly after the dividend announcement event, which indicates weak NASDAQ OMX Baltic market efficiency. Analysis of AARs results for separate years showed that computed AARs are significant with respect to all 3 strategies in 2015, and also significant in 2011 regarding the $2^{\text {nd }}$ and the $3^{\text {rd }}$ strategy with 95\% significance level. Analysis of NASDAQ OMX Baltic equity market efficiency in respect to dividend announcements indicates that when constructing stocks portfolio investors should not expect possible abnormal changes in stock prices because of the dividend announcement.

\section{References}

Aamir, M., \& Shah, S. Z. A. (2011). Dividend Announcements and the Abnormal Stock Returns for the Event Firm and its Rivals. Australian Journal of Business and Management Research, $1(8), 72-76$.

Abbas, G. (2015). Stock Prices Reaction to Dividend Announcements: A Study on Listed Companies in the Damascus Securities Exchange. International Journal of Academic Research in Accounting, Finance and Management Sciences, 5(1), 130-136.

Abouwafia, H. E., \& Chambers, M. J. (2015). Monetary policy, exchange rates and stock prices in the Middle East region. International Review of Financial Analysis, 37, 14-28.

Al-Yahyaee, K. H., Pham, T. M., \& Walter, T. S. (2011). The information content of cash dividend announcements in a unique environment. Journal of Banking \& Finance, 35(3), 606-612. 
Apergis, N., \& Miller, S. M. (2009). Do structural oil-market shocks affect stock prices? Energy Economics, 31, 569-575.

Awan, A. G., \& Bashir, I. (2015). Impact of Dividend Announcement on Share Price of Selected Listed Companies at KSE. Science International, 27(4), 3523-3527.

Borges, M. R. (2009). The Ex-Dividend Day Stock Price Behavior: The Case of Portugal. Atlantic Economy Journal, 36, 15-30.

Bozos, K., Nikolopoulos, K., \& Ramgandhi, G. (2011). Dividend signaling under economic adversity: Evidence from the London Stock Exchange. International Review of Financial Analysis, 20(5), 364-374.

Chan, W. S. (2003). Stock price reaction to news and no-news: drift and reversal after headlines. Journal of Financial Economics, 70, 223-260.

Chavali, K., \& Nusratunnisa (2013). Impact of Dividends on Share Price Performance of Companies in Indian Context. SDMIMD Journal of Management, 4(1), 4-9.

Chen, Q., Goldstein, I., \& Jiang, W. (2007). Price informativeness and investment sensitivity to stock price. Review of Financial Studies, 20(3), 619-650.

Chowdhury, J., \& Sonaer, G. (2016). Ex-dividend day abnormal returns for special dividends. Journal of Economics and Finance, 40(4), 631-652.

Cozorici, A. N. (2015). Dividend Policy, Signal Information for the Capital Market. USV Annals of Economics \& Public Administration, 15, 87-94.

Dasilas, A., \& Leventis, S. (2011). Stock market reaction to dividend announcements: Evidence from the Greek stock market. International Review of Economics \& Finance, 20(2), 302-311.

Dimitropoulos, P. E., \& Asteriou, D. (2009). The value relevance of financial statements and their impact on stock prices. Managerial Auditing Journal, 24(3), 248-265.

Eizentas, V., Krušinskas, R., \& Stankevičienè, J. (2012). Impact of public information signals on share prices: evidence from Lithuania. Economics and Management, 17(3), 879-888.

Faloye, B. A., \& Ouwole, F. O. (2014). Dividend Announcement on Share Prices in a Bull and a Bear Market Phase. Journal of Economics and International Finance, 6(12), 272-283.

Franc-Dabrowska, J. (2009). Does Dividend Policy Follow the Capital Structure Theory? Managing Global Transitions, 7(4), 367-382.

Gejalakshmi, S., \& Azhagaiah, R. (2015). Impact of Financial Meltdown on the Relationship Between Dividend Policy and Shareholders'Wealth. Management, 10(4), 355-377.

Goel, S. (2015). Dividend Policy and Market Price Behaviour in Indian Companies. Skyline Business Journal, 11(1), 46-52.

Haesner, C., \& Schanz, D. (2013). Payout Policy Tax Clienteles, Ex-dividend Day Stock Prices and Trading Behavior in Germany: The Case of the 2001 Tax Reform. Journal of Business Finance \& Accounting, 40(3-4), 527-563.

Hashemijoo, M., Mahdavi-Ardekani, A., \& Younesi, N. (2012). The impact of dividend policy on share price volatility in the Malaysian stock market.

Hussainey, K. \& Ngoc, L. K. (2009). The impact of macroeconomic indicators on Vietnamese stock Prices. The Journal of Risk Finance, 10(4), 321-332.

Jabłoński, B. \& Kuczowic, J. (2015). Strategies of Dividend Policy of the Companies Listed on the Warsaw Stock Exchange. Folia Oeconomica Stetinensia, June, 69-82.

Kim, J. \& Jeon, Y. (2015). Dividend Policy and Corporate Social Responsibility: A Comparative Analysis of Multinational Enterprise Subsidiaries and Domestic Firms in Korea. Emerging Markets Finance \& Trade, 51(2), 306-319. 
Laidroo, L. (2008). Public announcement induced market reactions on Baltic stock exchanges. Baltic Journal of Management, 3(2), 174-192.

Laidroo, L., \& Grigaliūnienè, Ž. (2012). Testing for asymmetries in price reactions to quarterly earnings announcements on Tallinn, Riga and Vilnius Stock Exchanges during 2000-2009. Baltic Journal of Economics, 12(1), 61-86.

Mallikarjunappa, T., \& Manjunatha, T. (2009). Stock Price Reactions to Dividend Announcements. Journal of Management \& Public Policy, 1(1), 43-56.

Manzoor, H. (2015). Impact of Dividends Announcements on Stock Returns Evidence from Karachi Stock Market. American Research Journal of Business and Management, 1(2), 25-36.

O'Reilly, D. M. (2009). Do investors perceive the going-concern opinion as useful for pricing stocks? Managerial Auditing Journal, 25(1), 4-16.

Peiró, A. (2016). Stock prices and macroeconomic factors: Some European evidence. International Review of Economics and Finance, 41, 287-294.

Pirie, S., \& Smith, M. (2008). Stock prices and accounting information: evidence from Malaysia. Asian Review of Accounting, 16(2), 109-133.

Rjoub, H., Türsoy, T., \& Günsel, N. (2009). The effects of macroeconomic factors on stock returns: Istanbul Stock Market. Studies in Economics and Finance, 26(1), 36-45.

Sim, N. \& Zhou, H. (2015). Oil prices, US stock return, and the dependence between their Quantiles. Journal of Banking \& Finance, 55, 1-8.

Stankevičienè, J., \& Akelaitis, S. (2014). Impact of Public Announcements on Stock Prices: Relation between Values of Stock Prices and the Price Changes in Lithuanian Stock Market. Procedia - Social and Behavioral Sciences, 156, 538-542.

Sulaiman, L. A. \& Migiro, S. O. (2015). Effect of dividend decision on stock price changes: further Nigerian evidence. Investment Management and Financial Innovations, 12(1).

Suwanna, T. (2012). Impacts of Dividend Announcement on Stock Return. Procedia - Social and Behavioral Sciences, 40, 721-725.

Tauseef, S. \& Nishat, M. (2015). The Ex-Dividend Day Stock Price Behavior: Evidence from Pakistan. Business Review, 10(1).

Văidean, V. L. \& Moza, C. Z. (2015). The Determinants of Dividend Policy - An Empirical Study. Review of Economic Studies \& Research Virgil Madgearu, 8(2), 107-124.

Vazakidis, A. \& Athianos, S. (2010). Do Dividend Announcements Affect The Stock Prices in The Greek Stock Market? International Journal of Economic Sciences and Applied Research, 3(2), 57-77.

Vega, C. (2006). Stock price reaction to public and private information. Journal of Financial Economics, 82(1), 103-133.

\section{Authors}

\section{Renata Legenzova}

Head of Finance Department

Vytautas Magnus University

Faculty of Economics and Management

S. Daukanto 28, 44246, Kaunas, Lithuania

renata.legenzova@vdu.It 


\section{Otilija Jurakovaite}

Vytautas Magnus University

Faculty of Economics and Management

S. Daukanto 28, 44246, Kaunas, Lithuania otilija.jurakovaite@vdu.It

\section{Agne Galinskaite}

Vytautas Magnus University

Faculty of Economics and Management

S. Daukanto 28, 44246, Kaunas, Lithuania agne.galinskaite@vdu.lt 